Portland State University

PDXScholar

$1-1-1970$

\title{
A survey of work facilities and rehabilitation services available to the handicapped in the United States
}

Morgan William Dickerson

Portland State University

Follow this and additional works at: https://pdxscholar.library.pdx.edu/open_access_etds

Let us know how access to this document benefits you.

\section{Recommended Citation}

Dickerson, Morgan William, "A survey of work facilities and rehabilitation services available to the handicapped in the United States" (1970). Dissertations and Theses. Paper 731.

https://doi.org/10.15760/etd.731

This Thesis is brought to you for free and open access. It has been accepted for inclusion in Dissertations and Theses by an authorized administrator of PDXScholar. Please contact us if we can make this document more accessible: pdxscholar@pdx.edu. 


\title{
A SURVEY OF WORK FACILITIES AND REHABILITATION SERVICES AVAILABLE TO THE HANDICAPPED IN THE UNITED STATES
}

by

MORGAN WILLIAM FISHER DICKERSON III

A Report submitted in partial fulfillment of the requirements for the degree of

\author{
MASTER OF \\ SOCIAL WORK
}

Portland State University

1970

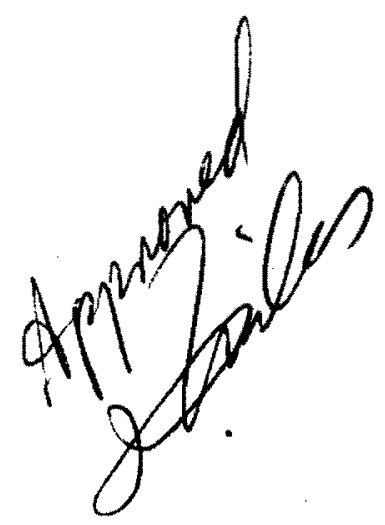


I. Purpose of Paper.......................

Area of study.........................

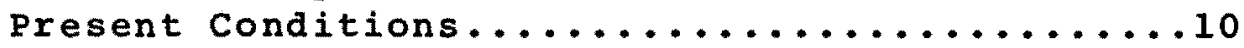

Federal Guidelines for Rehabilitation.......20

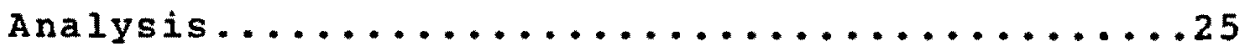

II. Values and Disvalues of Providing

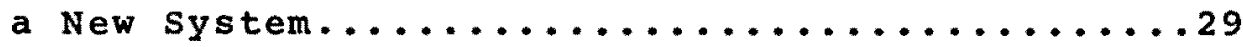

III. Proposal.........................

Means of service....................41

Facility...........................43

พages.............................. 44

Insurance...........................

Advancement.........................

Board of Directors....................46

Ultimate Goal.....................44

Planning Consideration.................48

Budget............................49

Program of services.................. 51

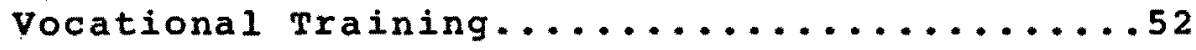

Counseling and Guidance................. 53

Job Placement....................... 54

Employment......................... 55

Educational programs................ 56

Vocational Areas...................... 57

Funding........................... 58

IV. Assessment Problems.................... 59

Bibliography.......................61

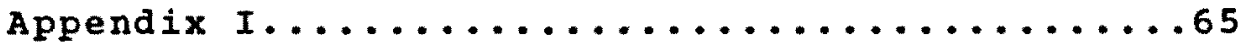

Appendix II........................67 


\section{A Survey of Work Facilities and Rehabilitation Services Available to the Handicapped in the United States}

During the administration of President John F. Kennedy the American public became aware that a segment of the population was being ignored, the mentally retarded. The president had a sister who was retarded. Unlike many families the Kennedys did not hide their handicapped daughter and deny her existence. President Kennedy donated his presidential salary to various charity organizations that worked with the mentally handicapped. When this was brought to light the public became more concerned with the "Retarded American".

Retardation, however, is not the only handicapping condition that prevents people from holding jobs. close investigation will show that there are many on the roles of welfare who could be employed if they were not classed as "Handicapped".

The purpose of this paper is to survey the work facilities and rehabilitative services available to the handicapped person in the United states. Information for this paper was obtained from The Department of Health, Education and Welfare, Goodwill Industries of oregon, library sources and the Department of Vocational Rehabilitation for many of the fifty states. 
Lois Huntly, in an article for the Journal of Rehabilitation, estimated that there were over four million persons in the United states eligible for rehabilitative services under the requirements set forth by federal and state vocational rehabilitative services in $1971^{1}$ Information obtained from state rehabilitation sources indicates this figure may not be accurate and that there are far more than four million handicapped persons in the United states. For example the state of California has a total of three million or more who are considered disabled.

of the more than four million mentioned as handicapped and eligible for services a very small percentage hold jobs in what is termed competitive industry. The indications are that the rest work in either sheltered workshops which provide training for non-skilled labor, or activity centers which are not designed to provide gainful long term employment. Those who are not in the aforementioned categories reside in family homes where they receive welfare or disability compensation or in state or private hospitals. Perhaps if there were more facilities geared to the needs of the retarded and

\footnotetext{
${ }^{1}$ Lois Huntly, "The problem. Possibility and Promise", Journal of Rehabilitation, October, 1971.
} 
severely handicapped some of these people could become employed and removed from the welfare roles.

With a new concept geared to the needs of the physically and mentally handicapped, money used to support the unemployed handicapped could be redirected into terminal workshops which would provide employment for those who are now considered "Unemployable" because of a handicap. Elias Katz in his book The Retarded Adult in the Community states, "Long term workshops are most urgently needed by large numbers of less able retarded adults. As more patients are moved out of state institutions for the retarded, this need will become greater. These workshops are virtually the only opportunities open for them to work at their own pace under supervision." 2 The same can also apply to the person who, through illness or injury, is now unable to meet the standards of industry. Both the physically and mentally handicapped must be provided some resources for employment besides those now in existence. By employing the handicapped person in a work setting geared to his specific needs we can help him to see himself in a more productive and satisfying manner. The funds used to subsidize the terminal

\footnotetext{
${ }^{2}$ Elias Katz, The Retarded Adult in the Community, Charles C. Thomas Publisher, Springfield, Ill., 1968.
} 
shop could be matched or exceeded if the shop produces several products which the public uses regularly but does not demand in rush quantities, such as ash trays or planters. The concept of a terminal workshop and it's products will be covered in more detail later in the paper.

According to statistics gathered in 1965 by the Department of Labor there were 787 workshops for the handicapped in the United States. The average number of clients served was 50. Approximately half of the shops employed less than 30 clients. Other shops such as Goodwill Industries of America served from 100 to 500 persons in some of their shops. ${ }^{3}$ with over four million handicapped persons living in our nation today it is painfully clear that there are not enough work facilities for the handicapped individual. Latest estimates of how many shops are now in existence show there has been no significant increase of shops since the 1965 figures were compiled. The closest estimate was that there were 800 functioning shops in the United states. ${ }^{4}$

oregon is a prime example of how short of workshops

${ }^{3}$ Elias Katz, op. cit.

${ }^{4}$ Lelia J. Zamir, Expanding Dimensions in Rehabilitation, Charles C. Thomas Publsiher, Springfield, Ill., 1969 pg. 168 
for the handicapped this nation is. In 1965 there were seven facilities serving handicapped workers. There are now, 1972, fourteen workshops and only two of these employ more than 50 workers. There is only one facility in the entire state that does pre-vocational evaluation of the handicapped. That facility is Goodwill Industries of Oregon. Portland's Goodwill program is the largest employer of handicapped in the state. There are approximately 435 clients working in the plant. In the evaluation unit twenty persons per month can be evaluated for work potential. Of these, four may be carried for a longer term for training in some nonskilled job. One may be hired as a worker, ten'may be placed in a work adjustment program to give them basic work skills the other five will be calssified as nonfeasible. 5

Data from California further substantiates the claim that the United states is short of rehabilitation facilities. In the past fiscal year (71-72) there were. 154 workshops in california and $3,391,860$ persons classified as disabled. This figure from California includes Veterans who may be employed but are receiving partial

\footnotetext{
${ }^{5}$ supplied to author by staff members of Goodwill Industries during staff meeting at Goodwill Industries of oregon, 1970
} 
government disabilities, amputees who may have lost a finger but recieved workman's compensation, etc. Pennsylvania records forty-one workshop facilities and 33,791 disabled persons.

on the average, each state's existing shops would have to employ nearly 800 persons per shop to give services to those who need them. This is not impossible but none of the existing shops are staffed to work with such large numbers. Goodwill of oregon has a staff of four to do evaluations. These four people are also responsible for working with the problems of the client workers, of which there are about 435. This makes it very difficult to maintain effective counsel for every client and taxes the abilities of each staff member.

A recent article in the Portland oregonian states that there are about 36,000 retarded children and adults in oregon. In order to service just the retarded for prevocational evaluation would take the states only evaluation center (Goodwill) it would take the four stafi members several years, and this obviously would exclude those with physical disabilities. 6

${ }^{6}$ oregonian, March 5, 1972 article by steve Erickson 


\section{AREA OF STUDY}

The area of interest for this paper is that of rehabilitation. By the term rehabilitation is meant, "To return to an individual the ability to function as he did before becoming handicapped by physical or mental illness, or in the case of those born with physical or mental handicaps, to make the individual capable of working successfully in "normal" working environments in spite of his limitations."

It could be argued that it is improper to "normalize" the handicapped. However one of the things often heard when counseling a handicapped individual is an expression of the wish to be like "normal" people. The desire to hold a decent job and to be self sufficient is as strong in handicapped as it is in most normal persons. It is also the stated wish of many political figures to give as little welfare as possible. The concept of a terminal subsidized workshop ought to help achieve their goal.

In the onited states most rehabilitation training is done in workshops which specialize in helping re-train or train handicapped persons in employment skills. such shops are often known by trade names such as "Goodwill Industries" or "Salvation Army". The term used to refer to these shops is "sheltered workshop". Sheiltered workshops serve only the upper level handicapped worker 
leaving those with severe problems unemployed. The concept of a terminal workshop is to take these severely handicapped employable persons and turn them into productive members of society.

Information and rules regarding rehabilitation programs can be obtained in bookẹ fort form through state rehabilitation agencies or through federal offices in washington, D.C. at the Department of Health, Education and Welfare, Social and Rehabilitation Services, Rehabilitation Services Administration, Washington, D.C. 20201. The informational packets contain expenditure date in dollars and cents, as well as the qualifications necessary to obtain state or federal funding. In fiscal year 1969, for example, 317 million dollars were available for use by rehabilitation programs in the United states. 7

Information obtained through letters, afticles and federal booklets indicates that there are over 7,000 sheltered workshops in the United states. This data includes all workshops utilizing handicapped persons which often includes small three person operations.

7 State Vocational Rehabilitation Agency Program Data, Rehabilitation Services Administration, social and Rehabilitation Services, U.S. Department of HeaIth, Education and Welfare, Washington, D.C., Appendix B pg. 12 
For this paper what is considered is the figure mentioned earlier, because for the purpose of this report a true workshop is one which employs ten or more handicapped persons in its operation and is designed to provide these people with some form of work training.

Lois Héntly's article mentioned earlier makes the inference that there are not enough facilities to hande all of the persons eligible for rehabilitation services.

The focal point of this paper will be those services which are presently available to the handicapped in sheltered workshops, and services which should be developed to provide rehabilitative services for these people. Also, the paper will point out certain weaknesses in some programs that are offered in the fifty states. The strong points of the present programs will be incorporated into the plan for improved services later in the paper. In the final assessment it is hoped that it will become evident that some radical change will have to take place before the "unemployable" handicapped will be able to support themselves without welfare aid. Some solutions can, and should take place immediately, others will require several years. 


\section{PRESENT CONDITIONS}

According to data compiled by the state Vocational Rehabilitation Agency Program Data, Rehabilitation Services Administration, Service and Rehabilitation Service and the U. S. Department of Health, Education and Welfare, in fiscal year 1964, 30,000 persons were served in rehabilitation facilities. An additional 8,000 were served in workshops; thus 38,000 were served in rehabilitation and workshop facilities. Some of the rehabilitation facilities were state operated programs similar to The Rehabilitation Institute of oregon, an institution which deals with giving treatment and training to those who have lost limbs in the use of prosthetic devices, and physical therapy to those who have lost the use of limbs. Most workshops deal in giving handicapped persons basic job skills rather than therapeutic treatment.

The 38,000 persons who received services in 1964, assuming that they are still working, represent 9.58 of the total handicapped work force in 1972. An additional 55,000 were added to those receiving service in 1969 or 16.88 of todays force were working. This group represented an increase of 7.38 of those needing services in a five year span. Since that time new recording methods have come into being. The new methods do not break down and distinguish between those served in work - 
shops and those who are served by rehabilitation facilities. But what these figures show is that at no time in the past eight years have services for the handicapped been adequate.

Need as defined by rehabilitation standards is, "those who for some reason have a handicap and because of this handicap are unable to be employed in spite of having a desire to be self supporting." some states require that a person or his family make application for services before the handicapped person is considered to be in need of rehabilitation service. It is through the use of such a requirement that Arizona can state that all the handicapped in the state are being served. This requirement effectively eliminates the families who have no knowledge of the services available through state offices of rehabilitation.

Having defined what "need" is, it becomes evident that, using the figures from 1964 and 1969 and projecting them to the present, more than $80 \%$ of the population needing services are not getting them. In 1970 services for the handicapped were received by 142,000 persons. This total subtracted from Huntly's four million eligible for services leaves $3,858,000$ persons who did not receive aid from established state rehabilitation agencies. Rehabilitation services again meaning services 
which will give a handicapped person skills or training which will help him to obtain some form of employment. From these figures it is confirmed that, as was mentioned in the projection earlier, more than $80 \%$ of the total handicapped population needing the services of rehabilitation agencies and workshops are not receiving care related to rehabilitation.

one important reason there were so many idle handicapped people was that existing workshops were not then and are not now able to adapt to the minimal worker. Those employed by sheltered workshops are, for the most part, persons whose performance is marginal; yet they are expected to maintain a high level of production in their work stations. If this level is not maintained the worker is called unfeasible and terminated.

High productive level, in workshop terms, implies a level of production which is one half of that of the non-handicapped worker. Such requirements eliminate the worker who is producing at $15 \%, 25 \%$ or $35 \%$. Those who are close to fifty percent in their production are kept until they fall below about $40 \%$ in all production areas.

Many workshops deal in reclamation of discards, such as do Goodwill Industries, Salvation Army, Volunteers 
of America and Union Gospel Mission. A few of these shops also will do low bid contract work supplied by firms looking for cheap labor to do trivial but necessary jobs. Examples of the latter are sorting of huc bolts (similar to cold rivets) used in the manufacturing of railroad boxcars or the packaging of stereo in-flight earphones used by passengers of many airlines. Both of these jobs require a steady output and in spite of their trivial nature require strict production and some degree of quality control. The schedules are not as rigid as those of regular industries but are often rigid enough to eliminate all but the better workers, resulting in many idle individuals who may be classed as unemployable.

Existing workshops are mostly independent of federal and state funding. Some have private funding but most rely on the sale of reclaimed goods in their outlet stores. These stores and shops are run in hope of making a large profit, as are most businesses. Very few shops have attempted to produce some product upon which they could depend for additional financial support. The closest they have come to this concept has been the use of contract work, which has proven to be unsatisfactory. It has been found that contract shops cannot make a profit 
due to the labor costs and the belief of industries providing contracts that handicapped persons do not need to make as much for their labor as the nonhandicapped. One noteable exception to this was a project utilized for many years by some blind workshops. (For many years some blind workshops manufactured and sold brooms at a slight profit.)

Few workshops have deviated from the "traditional" workshop model. Most administrators agree to a predetermined level or rate of productivity that has not been successfully challenged. As a result, no one has been willing to invest time or money in an attempt to disprove the traditional concept of workshop design. some workshop directors have taken the attitude that "No one else has successfully tried to switch to a product and I do not wish to be the next one to fail". Even though it can be pointed out that the blind shops for many years were successful making and selling brooms many have now closed. This is seen as proof that a shop cannot exist making a product. The real reason for the closure of the blind broom making shops is overlooked. In reality the reason for their failure was that they only had one product and it was replaced by a machine--the vacuum cleaner. Many workshops which deal in the reclaimation of discarded materials have noted an increase 
in the number of items made of plastic for example, however, if these items are broken they cannot be repaired nor can they bo sold. The cost of handing and storage alone is not worth the effort, but the directors of many shops would rather spend money to dump tons of plastic waste than spend the money to develop a small saleable product.

Few of the administrators in charge of workshops are trained in the fields of rehabilitation or social work. They are mostly business oriented, production minded individuals appointed by a board of like minded individuals who consider themselves "doing good" for the handicapped.

Most of the existing workshops considered to be major facilities stem from the early 1900 's when there was a great philanthropic surge. Salvation Army, Volunteers of America, Goodwill Industries are examples of organizations that were recipient of benevolent contributions of the Carnegie and Rockefeller foundations. The people who were in charge of these programs were ministers who, like Rockefeller, felt that it was their God given duty to aid those less fortunate than themselves, or businessmen who felt the same way. As the original directors died or retired they were replaced by others having similar backgrounds rather than by 
trained professionals in the rehabilitation and social work fields. The effect of such a progression is similar to that of expecting a used car salesman to practice dentistry on the basis of having seen a tooth pulled. It does, in many ways, tend to limit the effectiveness of the services rendered to the workers in these handicapped programs. For an example of how business procedures and rehabilitation methods clash one only has to interview the director of a production oriented workshop and his production manager, then interview the director of the rehabilitation program to see that they differ greatly as to their feelings about what their program has to offer the handicapped worker.

At the Portland Goodwill the director is a Methodist minister. He relies on the production manager's reports to determine how profits and labor costs are progressing. The production manager's prime concern is to get the maximum productivity from his workers. The worker who cannot produce is terminated. If the production manager and the director were at least trained slightly prior to working with the handicapped they would consider when terminating a worker referring that worker to one of the rehabilitation staff to determine why the person is not working productively.

There are many persons in the shops who have long histories of mental breakdowns. The rehabilitation staffs are aware 
of who these people are and the signs of possible breakdown. The production managers are often not willing to take time to consult with rehabilitation personnel or allow workers to take time from their jobs to seek aid when they need it. Workers who become disruptive on the job are terminated on the spot. There have been times at the Portland Goodwill when workers have had to be taken to one of the state mental hospitals directly from the plant. Often these trips could have been avoided if the production personnel and the director had been more aware of the problems of the client workers. 8

Another area which is part of the problem that some shops have is the board of directors. The usual makeup of these boards is that of successful businessmen who feel that the only way to run the workshop is to adhere to a rigid production schedule. They also place a great deal of faith in contract work. When a shop takes in contracts the board exerts pressure to the production managers who, in turn, aresin the position of expecting normal work performance from subnormal workers.

Many contracts are influenced by the seasonal swings of regular inductries. As a result in warm months there

\footnotetext{
${ }^{8}$ These statements and feelings were often voiced by members of the rehabilitation team while in staff development meetings during the two and a half years this writer was part of the team.
} 
are often more bids than can be handled and in cold months there is often the necessity of closing the shop or of laying off people. The first to go are the low producers. In other cases the people are terminated out-right. A workshop which had several secondary products to produce in slow seasons could avoid this problem. Items such as ash trays, aquariums or candles could be manufactured without strict and demanding schedules. It is toward these products sheltered shops should be headed.

During fiscal year 1969 the individual states spent a sum total of 54 milion dollars for the utilization of rehabilitation facilities. In 1970, 307 million was spent in case services (rehabilitation facilities under the new method of recording). The increase of funds for the handicapped on the surface appears to be admirable, however, only 258 of this money was utilized for direct service to the handicapped. Three fourths was used to pay staff members of the state vocational rehabilitation services. By using one fourth of the money allotted for client service the number of persons helped by rehabilitation facilities was severely limited. If a form of product could be established in existing workshops and a subsidy from state and federal sources made available, more people possibly could become 
employed in a terminal workshop. These people could then produce a useable product which could act as a source of revenue for the shop. The money from the sale of the product could also be utilized to expand facilities, or hire and evaluate others needing services.

In this sense services is meant, training, evaluation, work adjustment or actual employment. 


\section{EEDERAL GUIDELINES FOR REHABILITATION}

The Civil Rights Act of 1964 states, "No person in the United states shall, on the ground of race, color, or national origin, be excluded from participation in, be denied the benefit of, or be subjected to discrimination under any program or activity receiving Federal financial assistance." 9 Hence any program or activity supported by grants from Vocational Rehabilitation Administration, just as every program or activity receiving financial assistance from the Department of Health, Education and Welfare must be operated in compliance with this law. The washington lawmakers realized at this time that the handicapped had no such anti-discrimination law. The legislature acted to rectify this by passing Public Law 565 which is known as "The Vocational Act". This law states in part, "... to render the individual fit to engage in remunerative occupation ... and to provide the disabled individual with the rehabilitation services needed to achieve the best possible vocational adjustment." 10

${ }^{9}$ State Vocational Rehabilitation Agency, Fact Sheet Booklet, U.S. Department of Health, Education and Welfare, Fiscal year 1968, cover page

10 David Malikin and Herbert Rusalem, Edited by, Vocational Rehabilitation of the Disabled: An Overview, New York University Press, New York, 1969 pg. 112 
Paired with the civil Rights Act this should mean that all who are in need of rehabilitative services should be able to obtain them no matter how handicapped they are. In reality they do not because there are not enough programs and work facilities geared to their unique needs.

Under limits passed by congress funds are allotted to the states and territories by region in support of each of their basic vocational rehabilitation service programs. Funds are allotted by area population and per capita income.

Federal guides allow for the following services to the handicapped: ... "evaluation, including diagnostic and related services; counseling, guidance, training and placement services; reader services for the blind; interpreter services for the deaf; physical restoration services including, but not limited to corrective surgery for therapeutic purposes; necessary hospitalization in connection with surgery or treatment; prosthetic and orthotic devices; eye glasses and visual services as prescribed by a physician; maintainance not exceeding the estimated cost of subsistence; occupational licences; tools; equipment and initial stocks and supplies; transportation in connection with the rendering of any other vocational rehabilitation services; any other goods and services necessary to render a handicapped individual employable; 
and services to the families of handicapped individuals when such services will contribute substantially to the rehabilitation of such individuals.

Types of handicaps that have been accepted for services to the handicapped by the federal government are listed as either physical or non-physical. Under the heading of physical handicaps are: hearing, speech and function (inability to use basic communication skills); vision, which is divided into complete absence of sight, and visual impairment, which implies vision of $20 / 200$ with glasses (less than $20 / 200$ is considered to be total blindness); respiratory tuberculosis; asthma, and other chronic respiratory ailments; cerebral palsy; convulsive disorders; congenital malformities; impairment of endocrine functions; paraplegia; quadraplegia; impairments of genito-urinary systems; impairment of skin and subcutaneous tissue; hemoplegia; stroke; polio mylitis, and other forms of paralysis; multiple sclerosis; Parkinson's disease; nervous disorders; muscular dystrophy; cerebral vascular accidents without hemiplegia; low back cervical spine syndrome; arthritis; rheumatism; inflamatory and degenerative diseases of the bones, fractures, absence or loss of all or part of upper extremities; absence or loss of all or part of lower extremities; musculo skeletal 
disorders such as scoliosis; cardio-vascular diseases; peripheral vascular diseases; chronic sprains; soft tissue injuries; other conditions not covered elsewhere and unknown conditions and impairments.

Non-physical handicaps are: intellectual impairments, psychological or social impairment, and vocational and educational problems, mental retardation, mental involvements such as psychosis or neurosis which make a person nonfunctional, psychological and social impairment, alcholism, drug addiction, juvenile delinquency, emotional reaction to physical disability, chronic brain disorders, effects of social or cultural deprivation and unclassified disorders which would arise when any combination of these disorders might occur in one person." 11

In order for a rehabilitation program to obtain federal aid the above disabilities must be accepted. The legislature realized that without naming all the specific problems that can possibly occur some would be denied assistance by those who made value judgements about what, or if, applicants were handicapped. As it is, workshops often require complete physicals regardless of whether a prospective worker has his doctor's signed statement of an existing handicap or not. The ideal terminal shop

${ }^{11}$ State Vocational Rehabilitation Agency, Fact sheet Booklet, U. S. Department of Health, Education and Welfare, Fiscal year 1968. 
would be equipped to utilize any person in these categories effectively. 


\section{ANALYSIS}

Armed with figures which state that there are in excess of four million handicapped persons in the united states eligible for rehabilitation services and the fact that there are less than 1,000 workshops available to provide these people with services it becomes quite clear that there are not enough facilities to meet the needs of the handicapped. Assuming (since there are no figures on which to base an exact figure) arbitrarily that there are one million handicapped employed by non-rehabilitation oriented competitive industry one must be aware that a major portion of these persons have either a skill and/or above average intelligence which makes them a valued asset to their firms. Possible also are those who are "carried" by the firm because they are related to the "boss", but for the most part industries hire handicapped as a last resort. The severely handicapped person, on the other hand, remains unemployed and often inactive. Many of these people reside in. state or federally supported homes for the retarded and physically handicapped. From time to time articles in local papers appear stating that the conditions in these homes are less than adequate and that the care provided is substandard. In the past three years oregon's home 
for the retarded, Fairview, has been charged with giving inadequate care to its inmates.

State facilities for the retarded are seldom designed to make their inmates self-sufficient in the non-institutional world. Salem Rehabilitation Facility in oregon provides handicapped persons training in pallet making. However, there is not a large demand for pallet makers as the shipping firms that used to be a selling market for the shop's products are switching to reusable pallets made of plastic or metal. Use of wooden pallets is becoming a rarity, yet S.R.F. still trains people to make them. Such anachronisms are widespread.

There are persons who have spent their entire lives at Farview. One particular girl is of normal intellignece but unable to leave the facility because she has not been trained for any useful work. This young lady is twenty-one and confined to a wheel chair. She was left at the facility when only a few days old. She is just one of many at this particular facility who were seen during a field interview. The fact that there are others who if given access to training might have lived near normal lives outside of the home suggests a degree of inefficiency in our system. There are no programs which provide for life-span planning for the handicapped 
or for those who suffer from congenital birth defects.

A facility designed to privide job skills for these people, to provide them with counseling service and the possibility of gainful employment is needed. 
PART II

VALUES VERSUS DISVALUES

OF

PROVIDING A NEW SYSTEM 
This section will deal with the value of formulating a workshop program which can utilize the abilities of all but the bed ridden handicapped and to minimize pos:sible objections to such a program.

There are eight regularily used arguments which industrial employers use to justify not hiring handicapped workers. These arguments are not justified by research butt they are generally accepted by much of the working public. They are:

1. The handicapped person cannot do the job.

2. There are problems convincing supervisors that the person can work.

3. There are problems finding the right job for a handicapped person.

4. Lack of versitility.

5. Lack of promotability.

6. Workmans compensation laws (especially the second injury clauses)

7. Absenteeism.

8. Inability on the part of the handicapped worker (especially retarded) to observe safety regulations. Henry Kessler in his book Rehabilitation of the Physically Handicapped points out that studies on the physically handicapped have shown that the handicapped are good workexs. One study he mentions showed that 4,404 physically 
handicapped persons were engaged in 653 different types of work which point out the flaws in several of the above stated objections. The Ford Company has records confirming good work habits, high production rates and low accident rates for handicapped workers in its plants.

one local example of the ability of the handicapped to work and observe safety regulations is the Portland Goodwill. Twice in the last three years the state Accident Infurance Fund has presented the workers with awards for having achieved one million man hours without a lost time accident. This is equivalent of one person working for forty years without having an accident. When these records were broken by an accident only one of those having an accident was a handicapped person. No other industries in the state have matched this safety record. A well trained handicapped person from a well staffed workshop would be a safe worker because he would not be allowed to attempt an employment station away from the shop until he had demonstrated respect for safety regulations. Other studies show that the handicapped have a much better attendance records that non-handicapped workers. One need only look to General Motors' absentee records for Mondays and Fridays to realize normal workers are more likely to take a day off for less than valid reasons. 
Some of those who have hired handicapped persons were interviewed in the Kessler study and it was found that: 348 of those who hired handicapped felt these people were better workers than their "normal" staff; 30 \% found these people were less likely to quit a job (and if they did leave they gave appropriate notice); the handicapped had a better attendance records; were more conscientious; tried harder and were loyal workers. Having handicapped workers also acted as a positive factor in community relations for these firms. Finally, the argument that handicapped persons are not promotable is actually unrealistic in the light of the tendancy of most industries to promote people to a level of incompetance. The "Peter Principle" is often responsible for making it necessary to fill two spots rather than one: the one the person is promoted to, and is unwilling to take a pay cut to leave, as well as the job he left to take the promotion. A competant handicapped worker can be left at the job he does well and given proficiency pay increases withoug being promoted to a position that he cannot meet the requirements for.

Another possible argument that has been used more than once is that a training center for the handicapped would be an added hardship to these people's families to have to transport them to and from work. What is overlooked 
is that the handicapped and retarded often can, if given the chance, use public transportation. While the followingcases do not refute the above statement, they do point out what has been done at one workshop to take some of the burdon off of the families and place responsibility on the handicapped individual.

Two girls classified as severely handicapped individuals learned to ride the public busses from scappose daily, alone, in order to come to the main Goodwill facility at S.E. 6th and Mill st. in Portland, a distance of about thirty miles. An Arabian boy who spoke no English and was classified as being non-educatable commuted from Gresham alone, a distance of about fifteen miles. People who can learn this much can be used at least in a structured repetitive task, with a comparable amount of guidance to that it took to teach them to come to work alone.

Arguments against building new facilities are also many and varied. The cost of facilities, the competition of the facilities' product with those of other industries; seasonal shifts, provisions for retirement and pensions; the lack of qualified counseling staff, all can be assumed to be problem areas. The positive possibilities appear to this writer at least, to be worth investigating the formulation of terminal workshops on a serious basis. one of the basic needs of the human being is, according to the experts, the need for contact with other human 
beings in social gatherings. Such gatherings give the "normal" person a chance to socialize. The handicapped person has often been denied this contact with others and is uanble to socialize. A work setting would give the handicapped person contact with others and he would then be able to learn how to get along with and to relate to others better. He would be in the company of others who were also learning to take an interest in the world outside of their immediate families. Besides learning to get along with others these people would be learning a vocation. As one author has stated during interviews, "A vocation is a necessary ingredient of every successful 1ife. The need for a vocation is undoubtedly more important for the disabled."

one hears nearly each day some remark to the effect that people on welfare are lazy. The handicapped who are on the roles of welfare and want employment are lumped Into this "Lazy" group and they resent it justifiably. A facility designed for the handicapped to earn his own salary will make him feel that he is a productive member of society. In a society which values being independent a subsidized workshop for handicapped would be a blessing to many who are now unemployed. It would give the handicapped a degree of normalization in their daily routine. They too would have a job from eight to five and they 
would not have to rely on others for their support, thus becoming an infinite asset to both themselves and to the community as a whole.

Persons who develop good work skills and display an ability to work would be a new source of manpower when it is needed, also, it would reduce taxing for their support.

For the person who cannot work all day or at a high production rate a terminal workshop would provide a full time employment opportunity or one that is suited to their specific needs. For the person who has lost a limb and is learning to adjust to using a prosthesis the workshop could act as an occupational therapy program to assist the person back into the mainstream of 1 ife.

The way opportunities for the handicapped are now organized, life is a long series of impossed setbacks. "A child born with a malformation develops his first year, without an awareness of what has happened to him. soon it dawns on him that he differs from other children-that he has a handicap. 12

12 Adolph A. Apton, The Handicapped (A Challenge to the Non-Handicapped, Citadel Press, New York 1959 
"The normal (child) can satisfy his gregarious tendencies through ... various forms of group experiences. The retardates (or handicapped) however, frequently sense their own inferiority and are either rejected by their peers or feel so uncomfortable in their presence that they hesitate to seek group companionship."13 In adolescence "normal" children feel ugly and often have a hard time adjusting to the world. This problem is doubled for the handicapped adolescent, he must evaluate himself and his future which, because of a lack of programed life-space planning, is often bleaker than it need be.

Presently, there are few work oriented programs which offer the severely limited individual a "Normalized" working environment. As mentioned before, those who do not meet the production standards of existing work shops do not have the opportunity to gain the advantages of being with other people. In order to give the handicapped person the chance for a more meaningful and normalized life the proposal in part three is submitted as being an acceptable solution. It is recognized that with. the severity of handicap, efficiency is lowered which causes special costs and

13 Michael Begab, "Factors in Counseling Parents of Retarded Children", American Journal of Mental Deficiency, Vol 67, May-June, 1963, Pg. 520 
difficulties arise. The cost/benefit ratio makes it inadvisable for competitive or self-maintaining enterprises to hire handicapped persons as long as they can utilize non-handicapped workers. Subsidy to some enterprises will enable them to minimize their financial sacrifices. 14 workshops can give the handicapped the work values and with a product some sense of production schedules but some subsidy program must be developed to make insurance that industry will be willing to give the handicapped a larger portion of the work load.

${ }^{14}$ Dr. Frank Miles, Notes to writer unpublished. 
PART III

PROPOSAL 
A terminal workshop in contrast to the existing sheltered workshops would be geared to the needs of the severely handicapped individual. The shop would, however, be able to utilize the skills and provide some employment for those whose handicaps are not totally disabling. There would be facilities to evaluate work potential for persons referred through state rehabilitation programs and stations for apprentice training programs for the less handicapped and those whose handicaps are of a social and educational nature.

The proposed facility would feature a production schedule designed to maximize the abilities of the workers. For example: Those persons who are able to meet near normal production (trainees for apprentice programs) will be placed in a high level production line and pushed for maximum production. Those workers who cannot meet high levels will be graded accordingly, stationed in lesser production areas such as candle making or bolt. sorting for other work stations. In some areas there will be stations which will be manned by part time workers (those who have physicians clearance to do "light work") the person who can only work two hours will man these stations and be replaced at the end of his allotted time by a person with a similar problem, this way the station 
will always be in use during the work day.

The terminal shop will be a non-profit, charitable, educational, rehabilitation facility. It will meet the requirements of the federal and state governments as well as the requirements for accreditation of the National Rehabilitation Association. It will be able to provide all the potential vocational rehabilitation services needed by the physically and mentally handicapped as well as those needed by the socially and educationally handicapped. 


\section{MEANS OF SERVICE}

The terminal shop has as its primary goal the employment of the severely handicapped person and to provide these persons with skills of work that may increase their productivity and help them to become more self sufficient. The secondary goal will be the provision of rehabilitative services, educational and rehabilitative activities for the educationally deprived and socially handicapped as well as apprentice training and job development skills for those who might be employable in other work settingsoutside the shop. The method for providing these services will be: a. The making of useable low-demand items such as candles, ash trays, aquariums, flower baskets and planters.

b. The production of usable high demand items such as bicycles, furniture and kitchenware.

c. Contract work: A full time employee will develop and make contact with local firms for contract work which requires routine simple tasks which can be utilized for the low caliber workers and serve as evaluative tasks for new clients.

d. Utilization of recyclable goods obtained from the community through the use of contributions and clean-up crews. 
e. Sales of production items in local chain stores located throughout the community which will provide work and public relations expereince for client workers.

Income from the sales of the products from the shop in local stores, will be used to pay the workers. Any excess profits at the end of the year will be given to the workers as a bonus. The workers whose ability to work a full day is limited will be subsidized by both state and federal funds redirected from welfare disability (if the worker is receiving such aid and would rather work for what he receives). The staff Social Worker will be responsible for determining whether or not a worker is eligible for welfare and for making the necessary contacts to obtain funds for those who are eligible but not receiving aid. 


\section{EACILITIES}

The shop will be designed for the handicapped. All entrance ways will be ramp type for those in wheel chairs. All rest rooms will have adequate utilities for wheel chair clients. The shop will be a large one story building or if need be, a complex of one story buildings with convenient fire exits. It will be located near public transportation; for those able to use busses, for those who cannot ride the bus (wheel chair patients) transportation will be provided by the facility. 


\section{WAGES AND INSURANCE}

The wage scale for the plant will be such that those who are"terminal" workers will be paid the federal minimum wage of the times with provision for appropriate increases as the cost of living rises. This will be done on a subsidy of federal and state funds along with money from the sale of plant products. Those who are working in the high production portion of the plant or in the apprentice programs will receive piece rate pay, but no less than minimum wage.

Each worker will have coverage for health and workman's compensation. In order to utilize persons who previously have been injured in industrial accidents, the state or federal government will be asked to provide insurance, much the same way that they handie fidelity bonds for ex-convicts. The plant will also carry the other regular insurances. 


\section{ADVANCEMENT}

Workers will be able to advance to pay levels as their work skills increase. The ability of the severe cases while limited is not to preclude the possibility of improvement. Individual proficiency pay will also be utilized to give workers goals for which to work. Also, there will be provisions for longevity pay. 


\section{BOARD OF DIRECTORS}

The board of directors for this facility.will consist of an equal number of persons from business and from social work oriented communities. In this way input as to sound business procedures can be obtained and combined with the input as to the rehabilitation and social aspects of the program. 


\section{ULTIMATE GOAL}

The ultimate goal of the board and those in charge of the facility is to have a workshop for the handicapped and the severely handicapped run and staffed by handicapped. Each year colleges are turning out handicapped persons with the business skills and the practical knowledge of the needs of the handicapped. For the facility to be run by these people would appear the logical goal of helping the handicapped help themselves, and to provide incentive for such prior preparation. 


\section{PLANNING CONSIDERATIONS}

Services and facilities must be planned in terms of the levels of handicapping conditions, levels of retardation, age and the workers ability to work with others. The programs for placement in the plant must consider the need to assess each new client accurately. To do so will require:

- 1. Diagnostic and evaluative testing.

2. Work station observations.

3. Areas to aid the illiterate and socially deprived.

4. Staff to provide medical, social services, work adjustment and personal counseling.

5. daycare service.

6. Assessment of any creative talents which could be developed into income producing vocations. 


\section{BUDGEI}

Estimated cost of a facility designed to serve

four hundred employees per day would be:
400 clients per day at minimum wage (1.80 per hour) $\$ 14.40$ per day per person $x 400=\$ 5,760$. daily wages $\$ 5,760 \times 5$ work days $=\$ 46,080$ per week
$\$ 46,080$. x 5 weeks $=\$ 1,059,840$ per month
$\$ 1,059,840$. x 12 months $=\$ 12,718,080$. per year pay for clients

Income from evaluations would be $\$ 144,300$ per year at a cost to the referring agency of $\$ 14.92$ per person per day for evaluation of 50 clients per day. store sales totalling $\$ 3,300,000$. per year.

Income from enrollment in trade training programs for 100 persons at $\$ 50.00$ per day $=\$ 1,884,300$ per year. Income for work adjustment trainees at $\$ 25.00$ per day for 100 persons $=\$ 650,000.00$ per year.

Matching grants $=\$ 5,394,300.00$

Total yearly income $=\$ 10,788,600$

Salaries of clients $=\$ 12,718,080.00$

Income

Deficit

$$
\frac{10,788,600.00}{1,929,480.00}
$$

to be made up by redirecting welfare funds

staff salaries would be paid by grants from such organizations as National Institute for Mental Health, and groups having an interest in aiding the handicapped. These salaries would total approximately $\$ 163,000.00$ per year.

In order to estimate the most effective size of the ideal workshop, it will be necessary to project how many handicapped infants are born yearly. This will provide how many prospective clients the shop will 
have to serve in twenty years. From these figures it will be possible to project future needs and product development of the plant facility. At present only a few of the states used to collect data have such figures available. These figures are not enough to generalize nationally what the needs will be. 


\section{PROGRAM OF SERVICES}

The workshop will not exclude any person having a handicapping condition. However, each incoming prospect will undergo a period of evaluation to determine where he is presently functioning in relation to his handicap and to the other clients, also where he can best utilize any skills which he may have. This evaluation will include a medical, psychological, social and past work history. When these have been done a period of trials at various work stations will take place. The average evaluation time will be eight to twelve weeks. Evaluation of persons who are clients of the department of rehabilitation but considered prime candidates for regular employment will also be possible in an accelerated one week evaluation program which will utilize work stations geared to the person's skilis.

Persons who show behavior which might prevent them from being employed elsewhere will be provided a work adjustment training program which will emphasize proper work habits such as arriving at their job station on time, taking breaks and returning to the job at the appropriate time and any other job skills which they are found to lack. 


\section{VOCATIONAL TRAINING}

Vocational programs for those lacking in job skills will give clients some usable skill which they can use to obtain jobs in other industries. Those entered into this facet of the workshop will be those persons who, though handicapped, are capable of functioning but due to educational opportunities have not been able to fully develop useful job skills. These training stations will either be chosen by the client or have been agreed upon by the client and the referring Department of Vocational Rehabilitation counselor. 


\section{COUNSELING AND GUIDANCE}

Counseling and guidance services will be provided for each worker and evaluee. The counselor's responsibility will be to act as coordinator between the client, D.V.R., and his job supervisor. Any problem which arises in the client's work and adjustment to work will be handled through the counselor. The counselor will also be expected to keep the D.V.R. and the client aware of problem areas and to make it possible for the client to have personal counseling when he needs it or feels that he needs it, as quickly as possible. 


\section{JOB PLACEMENI}

Job placement will be available for those workers who show the ability to work in regular industry but do not have the state D.V.R. to act as their source of job referral. 


\section{EMPLOYMENI}

Employment for those workers who, because of severe retardation or physical handicap will be the primary program in the shop. Those persons who can do only simple repetitive tasks will be assigned to various projects in the. plant such as candle making. Some of these people will be used to move items from one area of the plant to another (if they are able to walk and use their hands to manipulate carts) others will be placed at sorting stations to seperate incoming salvage goods. 


\section{EDUCATIONAL PROGRAMS}

Programs to assist workers in improving skills such as reading and mathematics as well as some special interest programs such as photography or painting will be made available to all workers if it is felt that they may learn more. Mobility training for the blind and braille classes also will be available. Sign language and lip reading for the deaf and staff to aid in communicating might also be considered a useful educational tool. 


\section{VOCATIONAL AREAS}

Areas of training for vocations both in the plant and elsewhere which might be feasible work skills for clients are:

Photography cafeteria procedures material handing sewing

radio and $T . V$. repair

watch repair

- basic welding

filling station helper

truck helper

small engine repair

general drafting

bookkeeping

secretarial procedures

receptionist

duplicating procedures

candle making

glass work and repair

janitorial training

dry cleaning

spotting

pressing

sewing

clerking.

clothing sorting

toy repair

research and development of new products 


\section{EUNDING}

Persons being evaluated for the state D.V.R. will

be funded by contract to the state. The contract will be stated such that the evaluation of clients will be done on a monthly basis of the cost of time of the client's production rather than on a set salary. such a contract would allow the state to obtain evaluations for a minimal cost by supplying a set fee for each client.

Employees of the plant will be subsidized by state and federal funds which will allow them to make a minimum wage when their piece rate is added. In some cases the cost to the state and federal government could be as low as ten cents per hour while in others it might be 1008 of the worker's salary. 


\section{ASSESSMENT PROBLEMS}

In writing this paper several areas have presented problems. It was thought that it would be possible to determine the need for better rehabilitation facilities for the handicapped by pointing out the number of handicapped who were on the welfare roles of each state because they were too handicapped to hold steady jobs. This proved to be erroneous as most states could not give data on how many of their welfare recipients were handicapped. The Departments of Vocational Rehabilitation (D.V.R.) only could state the number of open cases they were presently carrying but could not project how many persons in the states were in need of service but had not applied.

None of the states had data on the number of retarded births or physical birth defects which had taken place, so that a projection of heed in the future could be made. No state broke its handicapped into age groups or sex groups. Federal estimates were not divided into any of the above groupings and at best were only rough estimates of how many persons fit in the category of handicapped. Their estimates were based on state records which, as was mentioned, were often incomplete. While there are many categories of handicap listed by the federal government there is no breakdown of how many persons fall into the various categories, either federally or by state. 
Existônt limitations in categories and data analysis reflect current limitations in perceiving and appreciating the nature, scope and ramifications of the problem of providing care for the "unemployable" handicapped. The most conclusive data available lends itself to the basic premise that: with more than four million handicapped in the United States and less than one thousand workshops, there is a need for more workshops; of those shops available few are willing to change their programs to utilize the severely handicapped person who is unable to produce at a rate of 508 the normal person's; there is a greater need for programs that can utilize the skills of these people regardless of how limited they may be. Also, we must gear ourselves to the returning viet-Nam veterans who are in need of rehabilitation services and job training. To employ these people at a living wage will require a shop subsidized by state and federal funds as well as by any products it can sell to aid in its survival. 


\section{SELECTED \\ BIBLIOGRAPHY}

\section{THESIS INSTRUCTION BOOKS}

1. Cordasco, Francesco and E. Gatner. Research and Report Writing. New York, Barnes and Noble, 1971. $142 \mathrm{p}$.

2. Van Hagan, Charles E. Report Writers' Handbook. New York, Dover Publications, Inc., 1961277 p.

3. Waldron, Rodney $K$. and Rita McDonald. Preparation of the Thesis. Corvallis, oregon, oregon state University Press, 1966. $28 \mathrm{p}$.

\section{REHABILITATION PROGRAM REPORTS}

4. Plue, William V., Edgar A. Taylor and Vernon Thomas. A Coordinal Program for Vocational Rehabilitation Services for the Mentally Retarded, project 1681. Vocational Rehabilitation Administration, Washington, D.C. and Portland Public schools, Augist 1968,127 numb. leaves.

5. A Focus on Rehabilitation in Oregon, Report of The Governor's Planning Committee on Vocational Rehabilitation. December 1968138 numb. leaves.

6. A Work Experience Program for the Mentally Retarded in Their Last Year in School (project R.D. 1736. Final Report Vocational Rehabilitation Administration and Goodwill Industries of oregon, (Don Grate project director). December 196765 numb. leaves.

7. Goodwill Job Description Manual. Goodwill Industries or oregon. No date available. 131 numb. leaves. 
9. The Predictive Assessment of the Adult Retarded for Social and Vocational Adjustment (A Review of Research) project R.D. 1624. Social and Rehabilitation Service Department of Health, Education and Welfare through Department of Psychology The University of South Dakota, Vermillion, South Dakota. 1969. 167 numb. leaves.

10. Vocational Evaluation programming in Workshops. University of San Francisco Rehabilitation Workshop Administration College of Business Administration. July 13, 1971. Collected Articles.

\section{STATE REHABILITATION PROGRAMS}

11. State of California. California state Plan for Workshops and Rehabilitation Facilities, 1971. Sacramento, California, July 1, 1971.

12. 1968 Directory of Rehabilitation Facilities. Listing of Facilities in the United states and Canada. Washington, D.C. 1968.

13. Directory of Rehabilitation Facilities, Workshops and clinics. Atlanta, Georgia, 1971.

14. National Directory of Rehabilitation Facilities 1970. U.S. Department of Health, Education and Welfare, Social and Rehabilitation Service, Rehabilitation Services Administration Division of Rehabilitation Facilities, washington, D.C. 1970.

15. North Dakota state Plan for Rehabilitation Facilities and Workshops. Division of Vocational Rehabilitation. Bismark, North Dakota, June 1968.

16. State Vocational Rehabilitation Agency. Fact sheet Booklet, U.S. Department of Health, Education, and Welfare, Social and Rehabilitation Service, Rehabilitation Services Administration, Washington, D.C. 1968. 
17. State Vocation Rehabilitation Agency. Program Data, U.S. Department of Health, Education and Welfare, Social and Rehabilitation Service, Rehabilitation Services Administration. Washington, D.C. 1969.

18. The 2nd Half Century, A Plan for Vocational Rehabilitation to 1975 and Beyond. Official Report of the Governor's Advisory Committee. New Jersey Comprehensive statewide Planning project for Vocational Rehabilitation Services. Trenton, New Jersey, August 30,1968 .

19. Utah State Plan and Resource Manual for Rehabilitation Facilities (revised). Utah state Board of Education. Salt Lake City, Utah, November 1, 1970.

20. Vocational Evaluation and Work Adjustment (a book of readings). Materials and Information Center Alabama Rehabilitation Media service. Auburn; Alabama, not dated.

\section{LIBRARY SOURCES}

21. Allen, $w$. Scott, Rehabilitation: A Community Challenge, John Wiley and Sons, New York, 1967.

22. Apton, Adolph A., The Handicapped (A Challenge to the Non-Handicapped), Citadel Press, New York 1959.

23. Furguson, Thomas, Agnes Kerr, Handicapped Youth, Oxford University Press, London, England, 1960.

24. Jaffe, A. J., Iincoln H. Day and Walter Adams, Disabled Workers in the Labor Market, The Bedminster press, Totowa, New Jersey, 1964.

25. Katz, Elias, The Retarded Adult in the community, Charles C. Thomas Publisher, springfield, Illinois 1968 .

26. Kessler, Henry H., Rehabilitation of the Physcially Handicapped, Columbia University Press, New York, 1949 
27. Malikin, Henry, and Herbert Rusalem, edited by, Vocational Rehabilitation of the Disabled: An Overview, New York University Press, New York 1969 .

28. Michaux, Louis A., The Physically Handicapped and the community, charles c. Thomas, Publisher, springfield, Illinois, 1970.

29. Tizard, J. and Jacqueline C. Grad, The Mentally Handicapped and Their Families (A social survey), Oxford University Press, London, England, 1961. 30. Zamir, Lelia J., Expanding Dimensions in Rehabilitation, Charles c. Thomas Publisher, springfield, Illinois, 1969. 


\section{APPENDIX I}

Regions used to determine funding from the Federal Government:

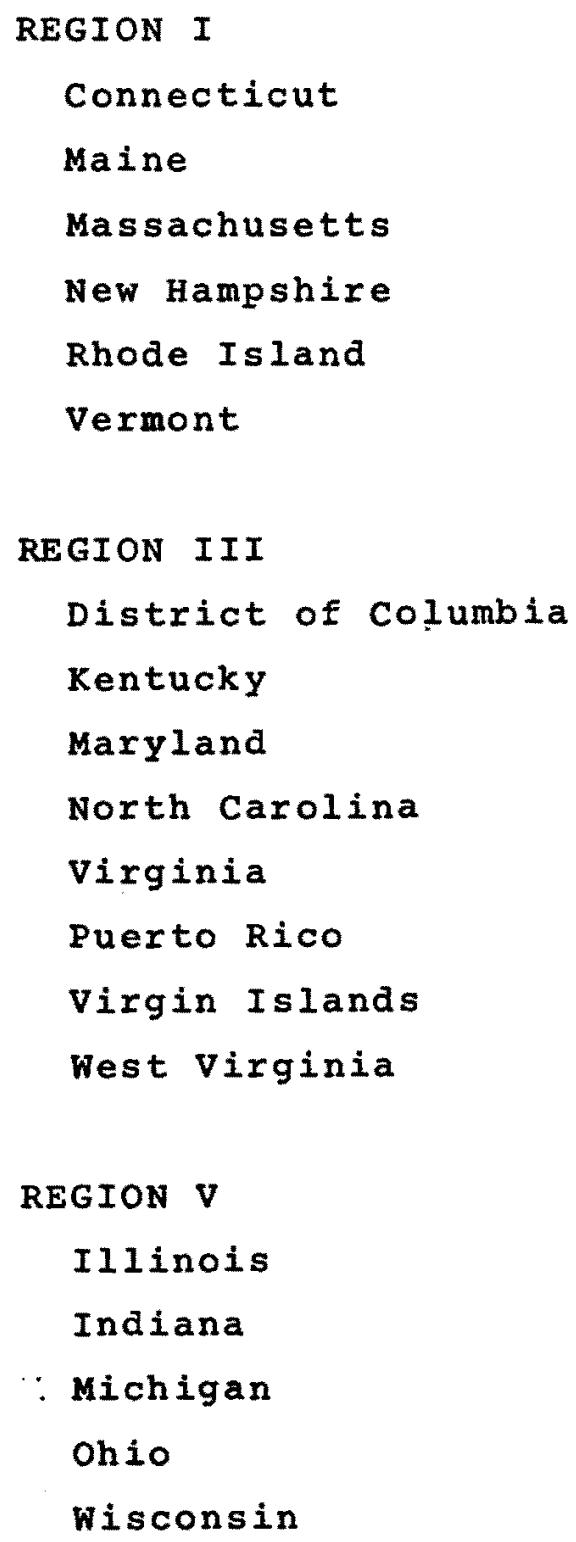

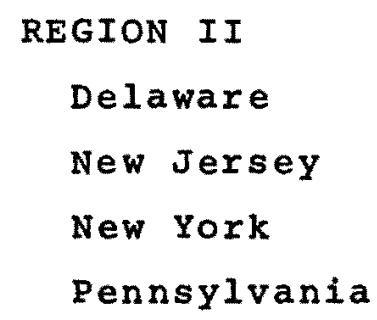


REGION VII

Arkansas

Louisiana

New Mexico

Oklahoma

Texas

REGION IX

Alaska

Arizona

California

Nevada

Hawaii

oregon

Washington

Guam
REGION VIII

Colorado

Idaho

Utah

Wyoming

Montana 


\section{APPENDIX II}

EXPENDITURE OF STATE VR AGENCY CASE SERVICE FUNDS IN REHABILITATION FACILITIES AND WORKSHOPS

FY 1961-1971 *

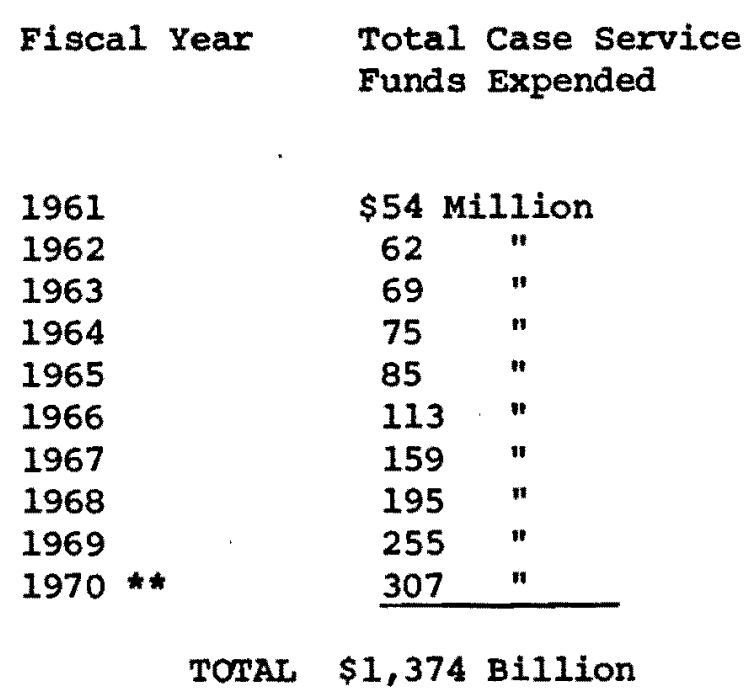

Case service
Spent in
$R F$ and WS

of Total Case Service Funds

Spent
in $\mathrm{RF}$

8 of

Spent

Total in WS

\& of $\mathrm{RF}$ and WS

$$
\begin{aligned}
& 11 \\
& 15 \\
& 17 \\
& 20 \\
& 22 \\
& 27 \\
& 26 \\
& 28 \\
& 24 \\
& 25
\end{aligned}
$$

$\$ 6$ Million

12 "

15 "

19 "

30 "

42 "

55 "

$62 "$

77 "

$\$ 327$ Million

$\begin{array}{ccc}\$ 10 & \text { Million } & 15 \\ 13 & \text { " } & 17 \\ 16 & \text { " } & 19 \\ 24 & \text { " } & 22 \\ 33 & \text { " } & 21 \\ 39 & \text { " } & 20 \\ 44 & \text { " } & 17\end{array}$

$\$ 179$ Million
$\$ 2$ Million 3

2113

3 " 4

6 *

9

18

56 Million

All Figures have been rounded off.

* Includes expenditures from General Agencies and Agencies for the Blind

** Under new reporting procedures there is no breakdown between the amount of funds spend in facilities in comparison to workshops.

Data compiled from "State Vocational Rehabilitation Agency Program Data," Rehabilitation Services Administration, Social and Rehabilitation Service, U.S. Department of Health, Education, and Welfare, Washington, D.C. 